\title{
Crónica
}

\section{SIMPOSIO PARA EDITORES DE REVISTAS CIENTÍFICAS CHILENAS EN EL ÁREA DE SALUD}

El 27 de mayo de 2005, se efectuó el VI Simposio para Editores de Revistas Científicas ChIlenas Área de Salud, convocado por la Asociación Chilena de Editores de Revistas Biomédicas (AChERB) y la Comisión Nacional de Investigación Científica y Tecnológica (CONICYT).

Se efectuaron los siguientes talleres:

1. El proceso de revisores por pares. Coordinadores: Drs Joaquín Palma (Revista Médica de Chile) y Francisco Cano (Revista Chilena de Pediatría).

2. Conflicto de intereses y cumplimiento de normas éticas. Coordinadores: Drs Manuel Oyarzún (Revista Chilena de Enfermedades Respiratorias) y Eduardo Rodríguez (Bioética).

3. Profesionalización e independencia del cuer- po editorial de las revistas científicas. Coordinadores: Drs Mariano del Sol (International Journal of Morfology) y Jorge Nogales-Gaete (Revista Chilena de Neuro-Psiquiatría).

4. Incorporación a índices bibliográficos y difusión de las revistas en páginas electrónicas. Coordinadores: Drs Sergio Gálvez (Medicina Crítica), José Cofré (Revista Chilena de Infectología) y Juan Carlos Weitz (Gastroenterología Latinoamericana).

En sesión plenaria se presentaron las conclusiones y recomendaciones de los talleres. Los comentarios finales fueron realizados por el $\mathrm{Dr}$ Humberto Reyes (Revista Médica de Chile) y Anna María Prat (Asesora de Presidencia de CONICYT).

\section{FIG O 2006 INTERNATIONAL FEШOWSHIP PROG RAMME}

The International Federation of Gynecology and Obstetrics (FIGO) and The Obstetrical \& Gynaecological Society of Malaysia (OGSM) are pleased to announce a joint initiative that will enable up to fifty young obstetricians and gynaecologists from developing countries to participate in a two-week programme at a Malaysian medical school and attend the XVIII FIGO World Congress, in Kuala Lumpur, Malaysia. The programme is organised in consultation with, and the generous support of, the Malaysian Ministry of Health.

The fellows will make scientific presentations at the Congress.

\section{Objectives of the International Fellowship Programme}

The objectives of the programme are:

- To demonstrate the real possibility of reducing maternal mortality significantly in developing countries by the systematic application of simple methods

- To establish and promote contact between obstetricians and gynaecologists worldwide.

- To promote cultural and professional exchange between Malaysia and practitioners from developing countries. 